\title{
Knowledge Strategy and Leadership and Their Roles in Change at Universities
}

\author{
Abobakr Aljuwaiber ${ }^{1}$ \\ ${ }^{1}$ Community College, Taibah University, Madinah, Saudi Arabia \\ Correspondence: Abobakr Aljuwaiber, Community College, Taibah University, Madinah, Saudi Arabia.
}

Received: October 8, 2019

Accepted: December 20, 2019

Online Published: January 6, 2020

doi:10.5430/jms.v11n1p17

URL: https://doi.org/10.5430/jms.v11n1p17

\begin{abstract}
The purpose of this paper is to bring to light a new perspective on the transformational role of universities by considering knowledge strategies for increasing research and academic capabilities. Change usually comes about because of a crisis in an organization; however, such change can also be due to permanent competition and rapid developments. As the world has moved into the twenty-first century, change has become indispensable, and organizations of many kinds face a variety of challenges. The first questions to ask are "Why change?" and "Why is change important?" Change is a fundamental factor behind an organization's success and can transform an organization into a global competitor. The three big factors that can impact a university are funding, leadership, and the research system, all of which have been directly affected by disturbances from the external environment and indirectly affected by changes to the university context in response to those disturbances. Many universities around the world have built good reputations, but they need to speedily react to future changes. Collaboration between universities and research institutes plays an essential role in developing the research context. In addition, associations based on specialist studies promote continued professional development among university staff. This paper therefore attempts to highlight the need for change in the realm of universities and answer questions regarding the whys and hows of such change.
\end{abstract}

Keywords: knowledge strategy, leadership, intellectual capital, universities, research, community, and business development

\section{Introduction}

At the current fast pace of life, changing concepts have become a prominent feature in many organizations and governments. Thus, managing change plays a crucial role in developing and improving such organizations. One of the sectors that require rapid change is education, particularly universities, because they have become more complex (Clark, 2003). Martin (2004) studied the seven key knowledge management (KM) success factors in universities, which are organizational culture, organizational management, leadership, information technology, KM strategy, KM measurement, and KM processes. In some countries (e.g., the UK and USA), competition in research among universities is fierce, which helps these universities in their endeavors to be leaders in a specific field of research (Turnbull \& Edwards, 2005). However, the challenge faced by universities' management is strong, as significant evidence shows that decision-making is affected by such issues as globalization, emerging research institutes, curriculum reform, and so on. Therefore, the desire for change has to primarily come through effective leadership and a focus on three aspects: (1) understanding through research, (2) empowerment through education, and (3) action through enterprise and engagement (Leliugiene \& Barsauskiene, 2007; Parra, 2010). Nonetheless, as Miles and Morrison (2018) stated, not all universities utilize their intellectual capital to engage with and support the development of businesses and communities.

A very recent study by Mascarenhas et al. $(2018$, p. 8$)$ pointed out a gap in research that investigates whether the relationship between a university and an industry constitutes a research strategy. This paper thus is not meant to provide an exhaustive literature review of possible change strategies within higher education institutions; rather, it is an attempt to highlight and provide an overview of the need for change at universities worldwide and facets where change is essential in the future. Conducting a literature review can be useful in developing conceptual or theoretical 
frameworks (Cronin et al., 2008). Consequently, this research argues that a typical view of knowledge strategy and leadership and their enablers (teaching and academic milieus) must reflect the community and business development in the university's change strategy. Moreover, this paper focuses on what the author sees as some important perspectives on change. Hence, the research proposes an integrated model of knowledge strategy and the role of leadership and its ability to make transformational changes in the university.

\section{Research Approach}

This research follows the suggestions of Aljuwaiber (2016) and Webster and Watson (2002) in adopting steps to achieve a constructed process to look for sources for this scholarly review. Accordingly, Google Scholar was the prime search engine used to identify relevant and high-quality research papers. Initially, "knowledge strategy," "leadership", "change", "higher education institutions" and "university" were used as the research keywords to be searched for in articles' titles and/or abstracts. This paper did not restrict the search to a given period of time. Of the articles found that included these keywords, peer-reviewed journal articles were selected for further review due to their greater validity.

\section{The University and Its Future Outlook}

Change has become one of the key issues in today's world, and two of the factors that play a substantial role in the inevitability of change are globalization and technological innovation in different fields. Other factors contributing to transformational changes in organizations include political parties, financial crises, technological revolution, and community trends (Burnes, 2009). According to Uys and Tulloch (2007), universities have been recognized as operating in an increasingly dynamic and frequently changing "volatile" global environment that calls for leaders to implement high-level changes. A recent study by Teixeira et al. (2019) argued that universities must rely on their leadership to be properly prepared and organized for future shifts. The role of universities has evolved, and their contributions to society and the economy are no longer limited to teaching and research (Beyhan \& Findik, 2018). PEST analysis (which stands for "Political, Economic, Social, and Technological") is a useful strategic tool for understanding the macro-environmental factors that are likely to determine the future of the university by conducting environmental scanning (Kotler, 1998). To this end, a review of existing studies (i.e., Beynaghi et al., 2016; del Mar Alonso-Almeida et al., 2015; Elena-Pérez et al., 2011; Formosa, 2014; Olcay \& Bulu, 2017; Teixeira et al., 2019) in Table 1 summarizes issues that may have an impact on universities in the future based on PEST analysis. The elements highlighted in the PEST analysis could guide universities to act quickly and respond to environmental threats before they cause hardship.

Table 1. PEST analysis - universities' future prospects

\begin{tabular}{ll}
\hline Factor & Description \\
\hline Political & Political factors cover various forms of government interventions and political activities in an \\
& economy. Specifically, political factors include policy in areas such as tax, labor, education, and \\
& environment, and changes to, the development of, and also include political stability (Ho, 2014). \\
& There are several factors that the current study has found that universities should take into \\
& consideration, for instance, (1) the impact of low carbon emissions, (2) presidential elections, (3) \\
& reduced support for universities, and (4) more direction/influence from the government.
\end{tabular}


All four factors presented above influence the path to change that a university can take and therefore require rapid action. For instance, some countries' electoral political systems will certainly bring changes to universities. In the Western world, some governments are stepping back from funding higher education (Turnbull \& Edwards, 2005). For example, Ribeiro-Addy (2010) reported that the Conservative party (in the UK) policy is of scrapping the existing target for half of all young people to join higher education. Hence, a university should find other funding sources, such as companies or communities, to support its activities in case of reduced government support.

In terms of branding strategy, it is vital that a university build a reputation for quality, especially in research. For instance, the Climatic Research Unit at the University of East Anglia (UEA) has a worldwide reputation, which helps the university make its research known in international forums (UEA, 2019). However, some projects require the participation of private businesses (Drori et al., 2013). Some universities develop successful partnerships with private businesses (Mascarenhas et al., 2018), yet a mismatch can occur between what businesses expect and what the university can deliver. Meanwhile, Chapleo (2010) raised the concern that some universities' image and reputation receive more attention and are more important than their actual teaching quality. Nonetheless, Chapleo (2010) emphasized that if a university has a clear and lasting vision and purpose, its brand will be successful.

Cooperation between higher education institutions and entrepreneurs is seen by researchers, policymakers, and media as vital to economic growth, job creation, and an increased standard of living in a country (Miller \& Acs, 2017). Universities play a crucial role in providing the entrepreneurial knowledge and skills necessary for enterprise growth, as well as in equipping individuals with adequate knowledge, skills, and abilities for proper business management (Yusuf \& Atassi, 2016). Moreover, universities help raise awareness of entrepreneurship as a career option for individuals, thus promoting an entrepreneurial spirit in society. The efficiency and integration of an entrepreneurial environment is one of the strategic means to a society's development and sustainability. Universities are an important component of human resources in the entrepreneurship ecosystem model.

Many university graduates wish to start up their own projects but may not have specific entrepreneurial skills, such as creativity, problem-solving, conflict management, communication, and negotiation. Lectures and business simulation games are often employed to teach these skills (Yusuf \& Atassi, 2016). Nevertheless, entrepreneurship among students and alumni receives less attention than it deserves (Beyhan \& Findik, 2018).

\section{Conceptual Analysis of Proposed Model}

As mentioned previously, leadership is seen to be crucial in making changes in organizations and is the subject of a lot of literature. Though there is some consensus among researchers about "the need for transformation, there is much less consensus around what transformed higher education should look like" (Khoo, 2017, p. 7). This paper thus argues that effectively implementing a knowledge strategy and leadership in a university and becoming a knowledge-based entity are seen as crucial for universities' success because of the influence of the era of the knowledge economy. Etzkowitz et al. (2000, p. 314) claimed that "universities can combine teaching, research and economic development in a common framework."

In the context of implementing an academic and research strategy in universities, the relative conceptualization of a knowledge strategy and leadership is depicted in Figure 1. This proposed model of a knowledge strategy that is linked to leadership identifies two main areas where a university could implement change.

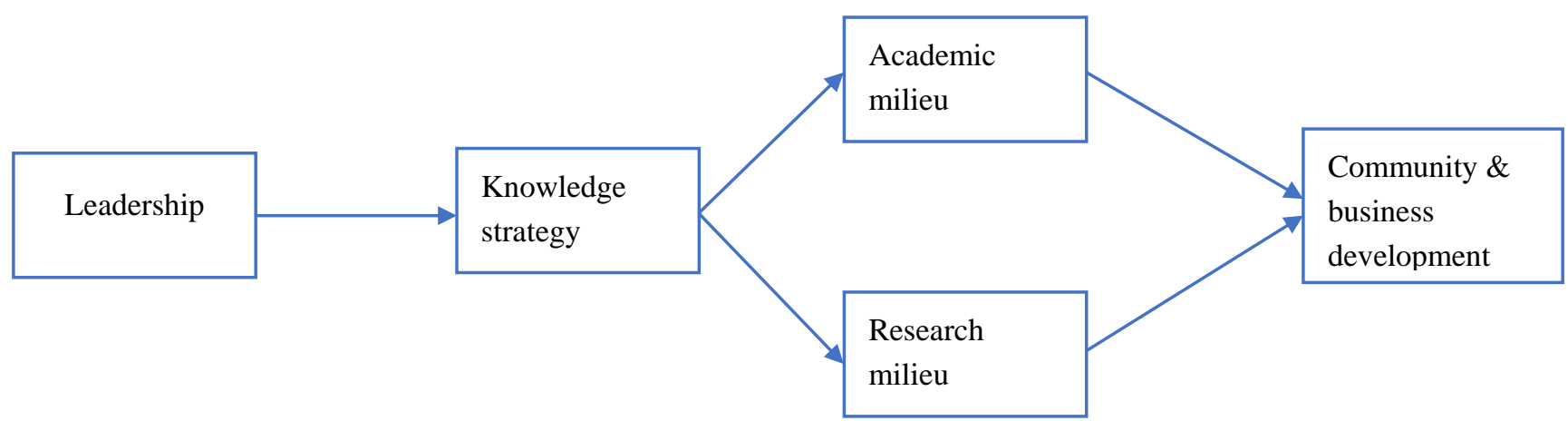

Figure 1. The proposed model of a knowledge strategy and leadership 


\subsection{Leadership and Its Role in Change}

Leadership can be defined as "influence leading to the achievement of desired purposes" (Spendlove, 2007, p. 408). This leadership theory contends that the behavior of leaders can significantly influence the behavior of others (Spendlove, 2007). Leadership plays a major role in change by formulating a new vision in a constant, sustained process of development to achieve success in an organization (Belias \& Koustelios, 2014). A university's leadership, as well as that of its departments, should take it upon itself to be different and align itself with global changes and challenges (Belias \& Koustelios, 2014; Bryman, 2007; Said et al., 2015). Noteworthily, university leadership may be principally different from business leadership and may require particular experiences and competencies (Spendlove, 2007). The vision of leaders is to focus more on a philosophy of change. It is normal for each university to have its own mission and vision, given the rivalry among educational institutions, but every university must at least be purposeful and align itself well with global challenges (Bryman, 2007).

Another issue that a university's leadership should consider carefully is employability. There is a great focus on postgraduate employability, so a university should have a distinctive academic structure that gives universities colleges flexibility to be directly connected through a university's executive team (Holmes, 2013). Another important issue that a university's leadership should take into account is a top-down focus on recruitment for a better studentstaff ratio, as this will affect student learning outcomes (McDonald, 2013). However, nothing is being done to focus on retention because of an unclear and bureaucratic promotion structure that provides little room for succession in some universities (Parker, 2013).

On the other hand, in terms of decision-making, decisions may not be clear, particularly when a group of powerful individuals can influence decisions (Locke \& Anderson, 2015). This concern has been mentioned in several studies, as most staff members have no power or influence over any decisions made at a university, as such power may be in the hands of the heads of the faculty when they meet during executive board meetings (Syed et al., 2012; Woessner $\&$ Kehler, 2018). Thus, the result could be that communication is limited and the power structure is opaque. The connection between professors and heads of faculty and their staff is vital and exists with a horizontally coherent and singular emphasis on business that goes directly up to the faculty level (Syed et al., 2012).

\subsection{Knowledge Strategy at Universities}

Universities are considered to be knowledge-intensive organizations with a high level of intellectual capital (Bratianu \& Bejinaru, 2017). Knowledge strategy is a concept that reflects the integration process of knowledge management and strategic management (Bratianu \& Bolisani, 2015). This means that knowledge is a strategic resource that can help in decision-making and transformational change. The notion of knowledge strategy is new, so there is no consensus on its definition. However, there is at least some agreement about its essential traits (Bratianu \& Bolisani, 2015). Zack (1999, p. 135) defined knowledge strategy as "the overall approach an organization intends to take to align its knowledge resources and capabilities to the intellectual requirements of its strategy." A knowledge strategy can also be viewed as "the employment of knowledge processes to an existing or new knowledge domain in order to achieve strategic goals" (von Krogh et al., 2001, p. 426).

Since knowledge is seen as an intangible asset, universities are considered to be a pool of knowledge assets and intellectual capital. Moreover, knowledge becomes an increasingly important part of innovation, as a university is considered to be a knowledge-producing and knowledge-disseminating institution that plays a bigger role in industrial innovation (Etzkowitz et al., 2000). Therefore, there is a need to figure out what sources of knowledge should be enhanced, what approaches could enable stakeholders' learning processes, and so on. Knowledge strategies are formed at the interface between the interior sphere of entities (e.g. colleges, departments) and the exterior field of entities for each organization (Bejinaru, 2017). Knowledge strategy initiatives deal with specific implementation details of approaches, administrative practices, and ICT infrastructures (Bratianu \& Bolisani, 2015). Bejinaru (2017) argued that the increasing stress of academic competition due to ranking systems has resulted in changes in governance. Furthermore, Bejinaru (2017) thought that these mutations are needed for new university leadership to make a connection between performance management and intellectual capital management.

One of the practical ways of gaining funding is through distance learning. Many universities now provide online master's programs through distance learning, especially MBA programs, in association with institutions that provide educational services. For example, the University of Liverpool offers a distance MBA in cooperation with Laureate Online Education. "The programme leads to the degree of MBA from the University of Liverpool but is being offered worldwide in partnership with Laureate Online Education. The mode of delivery is entirely by distance 
learning using the Internet. This enables students to pursue the programme via home study while continuing in employment - they can log in any hour of the day or night, participating at times that best fit their schedule. The programme has CEL accreditation from the European Foundation for Management Development. In addition, the programme comprises four core modules and four electives, as well as a dissertation which may concentrate on solving a workplace problem. Students normally take one module at a time, enabling them to explore a specific subject area in depth. Each taught module lasts for eight weeks, and it is possible to take a three-week break between modules if work or other commitments demand it" (University of Liverpool, 2019).

Now that the above two main engines that influence transformational change in universities have been explained, it is necessary to consider the two aspects that are influenced at most universities: the academic and research milieus.

\subsection{Academic Milieu}

One of the factors that could enhance academic curricula is the establishment of links with local communities and colleges as part of a university initiative. However, there is much work to be done in this aspect to solidify the university's vision. Some universities have a strategic vision regarding partnerships with private businesses (Othman \& Omar, 2012). However, this is more noticeable in some colleges than in others, where there is a possible mismatch between what a corporate entity expects and what the university can deliver.

Meanwhile, Mulà et al. (2017) argued that professional development in teaching for academics has not been prioritized at many universities and that they need to provide platforms for collaboration, sharing, networking, academic exchange, and peer learning. Existing research suggests that a network of people and organizations has become a vital strategy for exchange of expertise and knowledge and stimulating innovation (Kodama, 2011).

In terms of teaching, a university needs to consider and focus on the quality of its recruits, as well as take on the initiative of enhancing its staff-to-student ratio. Furthermore, universities should consider international study programs and global culture in formulating their vision. In fact, a true international strategy would have impacts on curricula, campus services, and all forms of engagement with a student body. Teixeira et al. (2019) contended that universities with global interests should make students more prepared for a globalized world.

\subsection{Research Milieu}

Regarding the research context, the greatest incentives for researchers are flexibility and autonomy in conducting their research. However, Bejinary (2017) thought that although universities have autonomy, they are still responsible for their performance and the realization of their missions. Alves et al. (2015), for instance, explained that, following 1992 legislation that allowed polytechnic schools (which focus on technical degrees) to become universities, many of these schools started to focus on research instead, resulting in the rise of the political view that there are too many universities and research centers in the UK and that government funding should be lessened by consolidating or cutting some of them.

Bratianu and Bejinaru (2017) perceived knowledge creation as the most powerful way to enhance a university's strategy, especially for research universities. At many universities, conducting research is perceived to be mandatory because of the organizational culture (Singh et al., 2013). Moreover, most world-class universities are recognized for their unique research programs and findings published in key international journals (Bratianu \& Bejinaru, 2017).

Notwithstanding, some universities have recently made great progress in establishing ties with research centers. For instance, the University of East Anglia has formed a partnership with Norwich Research Park (NRP), and four independent world-class research institutes (i.e. the Quadram Institute Bioscience (QIB), the Sainsbury Laboratory, the John Innes Centre, and the Earlham Institute) (UEA, 2019). Thus, the NRP is very well integrated with the UEA in terms of connection with the Faculty of Science and Norwich Medical School. The John Innes Centre has some institutional-political hurdles, but this partnership is also developing. Overall, the UEA has had real successes in building its relationship with the NRP, as there is a real sharing of vision between the two institutions.

\subsection{Community and Business Development}

This paper argues that combining the academic and research milieus would positively contribute to the development and prosperity of the community. Universities are no longer limited to teaching and research; rather, they are increasingly forced to turn to the outer perimeter (Leliugiene \& Barsauskiene, 2007). Meyer et al. (2019) indicated that some researchers conduct research for its own sake, whereas others do it to help others by using their studies to solve current and future management problems. Universities are recognized for their capability to contribute to the 
community through cultivating managerial, entrepreneurial, and technical talents (Miles \& Morrison, 2018). Stephenson (2011) attributed to university faculty, staff, and students the responsibility to help create and maintain an environment that encourages people to raise questions about their communities.

Nonetheless, very few studies have investigated collaboration between universities and businesses, especially in less-developed regions (Mascarenhas et al., 2018). This gap in research is due to universities' unclear strategies in their collaboration with businesses (Mascarenhas et al., 2018). Universities provide services to the community that could help develop the IT, educational, cultural, financial, and other industries (Leliugiene \& Barsauskiene, 2007).

\section{Recommendations for Change at the University}

Funding is one of the key concerns of many universities around the world at present, and these universities could search for private sources, including professional associations, to promote the continuing development of their staff in specialized areas. For instance, they could sign short- or long-term contracts with business firms that would help improve their funding situations (Parker, 2002). According to Parker (2002, p. 607), universities could improve their financial status "through international student recruitment, international courseware delivery, joint research projects with industry, commercialization of research outputs, corporate consultancies, corporate in-house training programmes, short course delivery to industry and commerce, and strategic alliances with professional and business bodies in providing postgraduate professional qualifying education."

In this era of technological development, universities need to enhance their utilization of technology, especially for educational purposes. For example, they could present some lectures through video feeds as part of their collaboration with other universities or even with businesses. In addition, they are in a prime position to promote carbon innovation. However, using advanced technology is not a priority of universities, as they prefer booking rooms and halls for conferences and meetings, which result in increased revenue (Siegel et al., 2003).

In terms of leadership, universities need an environment of transparency in which staff can share their opinions through organized meetings with chancellors and principals. Moreover, decisions should be measurable and realistic. A university strategy should not only exist on a piece of paper but create something that is practical with outcomes that can be measured. Thus, management should make bold decisions after conducting sufficient research. Also, it is crucial for the chancellor to hold annual meetings with the staff and students to answer questions, as well as to encourage them to put their efforts into developing the university. This paper conceives that the best approaches in universities involve a team of two: a transformational and visionary leader and a capable "get-it-done" deputy. This not only builds synergy but also provides the push/pull of constraint and enablement that is needed.

International students, on the other hand, are a very important input for the university, but it must understand their needs and provide them with a global environment through subjects and discussion examples related not only local issues but also to global ones. Talent recruitment, retention, and succession strategies are important for the survival of an organization, as well as for the provision of a competitive advantage.

\section{Conclusion}

This paper aimed to present a conceptual analysis of the roles of knowledge strategy and leadership in making changes in universities and to discuss key issues related to the aspects that universities' leaders should pay attention to. It has suggested a conceptual linkage between knowledge strategy and leadership as means of enhancing change at universities that reflects positively on the community and business development. The components of academics and teaching have been seen as crucial in the current research. Thus, separating teaching, research, and business activities is becoming less sustainable (Etzkowitz et al., 2000). Universities face pressure to make changes in their leadership and knowledge strategies to adapt to variations in the business and social settings. To align themselves with current needs, universities need to change, and people are key to these changes. Building strong strategic relationships both inside and outside the organization, such as with a government or businesses, would push universities toward development and change. Also, global partnerships, technology, and other facilities would bring advantages and flexibility to measures for improving these universities. Effective and efficient leadership, on the other hand, would help enhance decision-making through people's attitudes and behaviors. Despite the numerous studies on universities, various additional studies still need to be conducted to raise awareness of the relationship between the aspects of universities' leadership and knowledge strategies and their roles in introducing change and development for communities and businesses.

The key contribution of this research is that the presented model demonstrates the originality of the research in the 
field of strategic management within higher education institutions. It provides a platform for universities to establish how knowledge strategy and leadership can be used as strategic resources to promote the academic and teaching milieus by reflecting on the development of business and community. Thus, further study is encouraged to test this proposed model and to clarify the role of knowledge strategy and leadership within the university in making changes to and developing businesses and the community.

Several limitations in this paper are to be acknowledged. First, the current review may not have identified all the relevant papers published in journals. Therefore, some high-quality papers on knowledge strategy and leadership and their roles in changes within universities might not have been included in this review because of the restriction of the search to specific keywords. Second, the search was designed as a manual conventional search of a specific set of journals. Further studies could use a systematic literature review to produce stronger and more conclusive evidence on the roles of knowledge strategy and leadership in making changes in universities. This review, however, has presented fruitful thoughts that may provide fertile ground for further research on this topic.

\section{References}

Aljuwaiber, A. (2016). Communities of Practice as an Initiative for Knowledge Sharing in Business Organisations: A Literature Review. Journal of Knowledge Management, 20(4), 731-748. https://doi.org/10.1108/JKM-12-2015-0494

Alves, J., Carvalho, L., Carvalho, R., Correia, F., Cunha, J., Farinha, L., \& Nicolau, A. (2015). The impact of polytechnic institutes on the local economy. Tertiary Education and Management, 21(2), 81-98. https://doi.org/10.1080/13583883.2014.999110

Bejinaru, R. (2017). Knowledge strategies aiming to improve the intellectual capital of universities. Management \& Marketing, 12(3), 500-523. https://doi.org/10.1515/mmcks-2017-0030

Belias, D., \& Koustelios, A. (2014). The impact of leadership and change management strategy on organizational culture. European Scientific Journal, 10(7), 451-470. https://doi.org/10.19044/esj.2014.v10n7p\%25p

Beynaghi, A., Trencher, G., Moztarzadeh, F., Mozafari, M., Maknoon, R., \& Leal Filho, W. (2016). Future sustainability scenarios for universities: Moving beyond the United Nations Decade of Education for Sustainable Development. Journal of Cleaner Production, 112(4), 3464-3478. https://doi.org/ 0.1016/j.jclepro.2015.10.117

Bratianu, C., \& Bejinaru, R. (2017, April 6-7). Knowledge strategies for increasing IC of universities. In I. T. Lopez \& R. Serrasqueiro (Eds.), Proceedings of the 9th European Conference on Intellectual Capital (pp. 34-41). Instituto Universitario de Lisboa, Lisbon, Portugal.

Bratianu, C., \& Bolisani, E. (2015). Knowledge strategy: An integrated approach for managing uncertainty. In Proceedings of the 16th European Conference on Knowledge Management (pp. 169-177).

Bryman, A. (2007). Effective leadership in higher education: A literature review. Studies in Higher Education, 32(6), 693-710. https://doi.org/10.1080/03075070701685114

Burnes, B. (2009). Managing change (5th ed.). Harlow: Financial Times Prentice Hall.

Clark, B. R. (2003). Sustaining change in universities: Continuities in case studies and concepts. Tertiary Education and Management, 9(2), 99-116. https://doi.org/10.1023/A:102353811

Cronin, P., Ryan, F., \& Coughlan, M. (2008). Undertaking a literature review: a step-by-step approach. British Journal of Nursing, 17(1), 38-43. https://doi.org/10.12968/bjon.2008.17.1.28059

Del Mar Alonso-Almeida, M., Marimon, F., Casani, F., \& Rodriguez-Pomeda, J. (2015). Diffusion of sustainability reporting in universities: Current situation and future perspectives. Journal of Cleaner Production, 106(1), 144-154. https://doi.org/10.1016/j.jclepro.2014.02.008

Drori, G. S., Delmestri, G., \& Oberg, A. (2013). Branding the university: Relational strategy of identity construction in a competitive field. Trust in Higher Education Institutions, 134-147.

Elena-Pérez, S., Saritas, O., Pook, K., \& Warden, C. (2011). Ready for the future? Universities' capabilities to strategically manage their intellectual capital. Foresight, 13(2), 31-48. https://doi.org/10.1108/14636681111126238 
Etzkowitz, H., Webster, A., Gebhardt, C., \& Terra, B. R. C. (2000). The future of the university and the university of the future: Evolution of ivory tower to entrepreneurial paradigm. Research Policy, 29(2), 313-330. https://doi.org/10.1016/S0048-7333(99)00069-4

Formosa, M. (2014). Four decades of Universities of the Third Age: Past, present, future. Ageing \& Society, 34(1), 42-66. https://doi.org/10.1017/S0144686X12000797

Hemsley-Brown, J., Lowrie, A., \& Chapleo, C. (2010). What defines "successful" university brands?. International Journal of Public Sector Management, 23(2), 169-183. https://doi.org/10.1108/09513551011022519

Ho, J. K. K. (2014). Formulation of a systemic PEST analysis for strategic analysis. European Academic Research, 2(5), 6478-6492.

Holmes, L. (2013). Competing perspectives on graduate employability: Possession, position or process?. Studies in Higher Education, 38(4), 538-554. https://doi.org/10.1080/03075079.2011.587140

Khoo, S.-M. (2017). Sustainable knowledge transformation in and through higher education: A case for transdisciplinary leadership. International Journal of Development Education and Global Learning, 8(3), 5-24. https://doi.org/10.18546/ijdegl.8.3.02

Kotler, P. (1998). Marketing management-Analysis, planning, implementation, and control (9th ed.). Englewood Cliffs: Prentice-Hall.

Leliugiene, I., \& Barsauskiene, V. (2007). The role of the university in community development: Responding to the challenges of globalization. In D. Bridges, P. Juceviciene, R. Juceviciene, T. McLaughlin, \& J. Stankeviciute (Eds.), Higher Education and Development: Universities and Societies in Transition (pp. 227-235). New York, New York: Routledge.

Locke, C. C., \& Anderson, C. (2015). The downside of looking like a leader: Power, nonverbal confidence, and participative decision-making. Journal of Experimental Social Psychology, 58(1), $42-47$. https://doi.org/10.1016/j.jesp.2014.12.004

Martin, J. S. (2004). Enhancing and inhibiting interactions between business processing and knowledge production: A macro study of leadership and knowledge processing in higher education. Doctoral dissertation, Clemson University.

Mascarenhas, C., Ferreira, J. J., \& Marques, C. (2018). University-industry cooperation: A systematic literature review and research agenda. Science and Public Policy, 45(5), 708-718. https://doi.org/10.1093/scipol/scy003

McDonald, G. (2013). Does size matter? The impact of student-staff ratios. Journal of Higher Education Policy and Management, 35(6), 652-667. https://doi.org/10.1080/1360080X.2013.844668

Meyer, M., Debackere, K., Grant, K., Kuusisto, J., Kume, O., \& Yu, T. (2019). Universities, user-driven competence centres and intellectual property. Les Nouvelles-Journal of the Licensing Executives Society, 54(2), 112-119. Retrieved from https://ssrn.com/abstract=3380461

Miles, M. P., \& Morrison, M. (2018). An effectual leadership perspective for developing rural entrepreneurial ecosystems. Small Business Economics, 1-17. https://doi.org/10.1007/s11187-018-0128-z

Mulà, I., Tilbury, D., Ryan, A., Mader, M., Dlouhá, J., Mader, C., \& Alba, D. (2017). Catalysing Change in Higher Education for Sustainable Development. International Journal of Sustainability in Higher Education, 18(5), 798-820. http://doi.org/10.1108/ijshe-03-2017-0043

Olcay, G. A., \& Bulu, M. (2017). Is measuring the knowledge creation of universities possible?: A review of university rankings. Technological Forecasting and Social Change, 123(1), 153-160. https://doi.org/10.1016/j.techfore.2016.03.029

Othman, R., \& Omar, A. F. (2012). University and industry collaboration: towards a successful and sustainable partnership. Procedia-Social and Behavioral Sciences, $\quad 31(1), \quad 575-579$. https://doi.org/10.1016/j.sbspro.2011.12.106

Parker, L. D. (2002). It's been a pleasure doing business with you: A strategic analysis and critique of university change management. Critical Perspectives on Accounting, 13(5-6), 603-619. https://doi.org/10.1006/cpac.2002.0561 
Parker, L. D. (2013). Contemporary university strategising: The financial imperative. Financial Accountability \& Management, 29(1), 1-25. https://doi.org/10.1111/faam.12000

Parra, Y. J. F. (2010). Research as a means of empowering teachers in the 21st century. Educación y Educadores, 13(1), 109-124. https://doi.org/ 10.5294/edu.2010.13.1.7

Ribeiro-Addy, B. (2010, April 12). Universities need investment not cuts. Retrieved from http://www.guardian.co.uk/commentisfree/2010/apr/12/universities-need-investment-not-cuts

Said, H., Ahmad, I., Mustaffa, M. S., \& Abd Ghani, F. (2015). Role of Campus Leadership in Managing Change and Challenges of Internationalization of Higher Education. Mediterranean Journal of Social Sciences, 6(4), 82-88. https://doi.org/10.5901/mjss.2015.v6n4s1p82

Sarawanawong, J., Tuamsuk, K., Vongprasert, C., \& Khiewyoo, J. (2009). Development of a strategic knowledge management model for Thai universities. In Proceedings of the Asia-Pacific Conference on Library \& Information Education \& Practice (pp. 288-298).

Siegel, D. S., Waldman, D. A., Atwater, L. E., \& Link, A. N. (2003). Commercial knowledge transfers from universities to firms: Improving the effectiveness of university-industry collaboration. Journal of High Technology Management Research, 14(1), 111-133. https://doi.org/10.1016/S1047-8310(03)00007-5

Singh, P. K. H., Thuraisingam, T., Nair, V., \& David, M. K. (2013). The research imperative in the evolving environment of public universities in Malaysia. SEARCH: The Journal of the South East Asia Research Centre for Communication and the Humanities, 5(1), 1-18

Spendlove, M. (2007). Competencies for effective leadership in higher education. International Journal of Educational Management, 21(5), 407-417. https://doi.org/10.1108/09513540710760183

Stephenson, M. (2011). Conceiving land grant university community engagement as adaptive leadership. Higher Education, 61(1), 95-108. https://doi.org/10.1007/s10734-010-9328-4

Syed, A. A. S. G., Bhatti, N., Michael, S., Shaikh, F. M., \& Shah, H. (2012). Job satisfaction of faculty members of universities in Pakistan: A case study of University of Sindh-Jamshoro. Modern Applied Science, 6(7), 89-95. https://doi.org/10.5539/mas.v6n7p89

Teixeira, A. M., Bates, T., \& Mota, J. (2019). What future(s) for distance education universities? Towards an open network-based approach. Revista Iberoamericana de Educación a Distancia, 22(1), 107-126.

Turnbull, S., \& Edwards, G. (2005). Leadership development for organizational change in a new UK university. Advances in Developing Human Resources, 7(3), 396-413. https://doi.org/10.1177/1523422305277178

Tushman, M. L., \& Anderson, P. (2004). Managing strategic innovation and change: A collection of readings (2nd ed.). New York: Oxford University Press.

University of East Anglia. (2019). Corporate plan: 2008-2012. Retrieved from https://www.uea.ac.uk/documents/3154295/0/UEA+Corporate+Plan+2008-2012.pdf/7fe412e5-d6db-4e4c-8a1f$1 \mathrm{ab} 6 \mathrm{e} 3 \mathrm{e} 3 \mathrm{bb} 65$

University of Liverpool. (2019). Online master of business administration (MBA). Retrieved from http://www.liv.ac.uk/study/postgraduate/taught_courses/laureate_online_mba.htm

Uys, P. M., \& Tulloch, M. (2007). Appropriate change leadership for the introduction of flexible learning within university governance and strategic leadership frameworks: A comparative analysis of case studies in developed and developing countries. Paper presented at the Integrating for Excellence Conference 2007, Sheffield, UK.

Von Krogh, G., Nonaka, I., \& Aben, M. (2001). Making the most of your company's knowledge: A strategic framework. Long Range Planning, 34(4), 421-439. https://doi.org/10.1016/S0024-6301(01)00059-0

Webster, J., \& Watson, R. T. (2002). Analyzing the past to prepare for the future: writing a literature review, MIS Quarterly, 26(2), 13-23. Retrieved from https://www.jstor.org/stable/4132319

Woessner, M., \& Kehler, J. (2018). Faculty constitutions in the ivory tower: Exploring the balance of power between the professoriate and the administration. PS: Political Science \& Politics, 51(2), 387-395.

Zack, M. H. (1999). Developing a knowledge strategy. California Management Review, 41(3), $125-145$. https://doi.org/10.2307/41166000 